\title{
Meeting Cultures and Languages in the Classroom - Rethinking Aronson's Method ${ }^{1}$
}

\author{
Kolosai Nedda*
}

DOI: 10.21549/NTNY.34.2021.3.5

Prejudices unconsciously influence the actors in school life, and may unintentionally hinder opportunities of equal access to learning, because teachers speak 'another language', use other language codes which many children are unable to decipher. By adapting and re-thinking the Aronson mosaic method, our research team has developed an innovative circular classroom learning model that creates opportunities for the validation of different aspects in teaching. The study seeks answers to the following questions: Which aspects of the Circular Learning method make it possible to compensate for cultural and linguistic differences? What factors can make peer-to-peer education effective from the children's perspective? We studied mutual learning and teaching by peers in spring 2018, when 284 children and 74 trained adult observers took part in the process. We studied the complex pedagogical and educational process in 30 classes in 3 schools, in 4 times 45 -minute activities in each class, factors that reinforce the validity of the research and its results. We processed the quantified answers of Children and Adults Assessment Forms in two ways. 1) An R Statistical Program and SPSS Statistical Program in which test groups were compared with a two-sample t-probe. Correlation calculations were performed using the Spearman correlation coefficient at alpha $=0.05$ significance level, which we corrected through Holm's method for multiple hypothesis testing. 2) We processed the answers of both children and adults by qualitative content analysis. The learning organization procedures used in our research model create opportunities for children from different cultures, with different mother tongues and of very different socio-economic status (diversity) for learning, equal access to knowledge (equity), cooperation with each other, and equality, as well as mutual understanding (sustainability). Currently in Hungary and worldwide, developing the ability of children to integrate into another person's way of thinking is of great importance. Ensuring the perspective of others, in addition to the effectiveness of learning, is a significant factor in developing empathy.

Keywords: Circular Learning method, peer- to-peer education, perspective, children's voices

\section{Problem statement}

Currently in Hungary and worldwide it is a general phenomenon that teachers in the classroom work with children from a variety of cultures and with various mother tongues. At the same time, a great deal of research indicates that the cultural gap between children and teachers is steadily increasing. Teachers tend to focus mainly on the material to be learnt and the teaching process itself. Less attention is paid to evening out cultural and linguistic differences between the children and between them and adults.

1. Acknowledgments: This study was supported by the Hungarian Academy of Sciences within the framework of the Subject Pedagogical Research Program.

* Associate professor, ELTE Faculty of Primary and Pre-School Education, Department of Education, e-mail: kolosai.nedda@tok.elte.hu 
Prejudices unconsciously influence the actors in school life, and may unintentionally hinder opportunities of equal access to learning, because teachers speak 'another language', use other language codes which many children are unable to decipher. When children perceive differences, whether great or small, between their classmates and themselves, they usually respond with rejection. Can the secondary disadvantages resulting from linguistic and cultural differences be reduced by rethinking the methods of learning and teaching? How can children be brought closer together by teaching methods creating equal opportunities for accessing knowledge?

When examining pedagogical methods which in our case are cooperative in structure, in the implementation of an organizational learning method it is not the purity of the method that matters. The micro-level (for instance, the classroom) and macro-level social issues to which we apply the method should always be borne in mind. It is important that researchers face those problems as well as how to solve them by using applied techniques (Popper, 1997).

\section{Creating opportunities through the Circular Learning model}

We created a classroom learning model called Circular Learning that might provide solutions to the problems outlined above. With the research-based development of the method, we have tried to integrate several, in themselves complex, systems of criteria in accordance with our genuinely opportunity-creating goals. In line with international and Hungarian models (Garcia, Rivera \& Greenfield, 2015; Gordon-Győri, 2017), our set of methods is both a knowledge- and an opportunity-creating model.

The elements of our system of criteria comprise:

I. equality,

II. equity or equal equity,

III. diversity,

IV. excellence,

V. social/economic sustainability.

Our continuously evolving Circular Learning model creates an opportunity to jointly apply the above system of criteria in teaching. The learning model is able to harmonize (1) the social needs of social integration, opportunity creation and social sustainability (Gordon-Győri, 2017; Halász, 2017; Knausz, 2017); (2) educational values; as well as (3) the cognitive goals of teaching (e.g. applicable knowledge). The aim of our research is to develop a general (feasible) and paradigmatic model that goes beyond the level of techniques and can be used to set up institutional, system-level models for the longer term (Arató, 2010). In that longer term, our aim is to make possible the application of the research model in the system of public education - in everyday pedagogical practice - thus providing elegant, simple and socially valid responses to the changing roles of teachers and students in the classroom (Arató, 2010a, 2010b; Wilson \& Demetriou, 2007).

\section{Establishing a community of practice}

We have consciously incorporated meaningful cooperation with practising professionals into our program development. Research tasks and goals were accomplished jointly. We have created communities of practice that are able to reach and change the deepest levels of teaching practice in the "co-production" of quality. In these communities of practice (Halász, 2017) we articulate - with teachers, university students, educational 
researchers and children - our set of teaching methods as a kind of continuous dialogue between theory and pedagogical practice.

The way we construct knowledge, and which aspects of it can be an effective complement to our direct interaction with the teacher, is how we define Circular Learning. We collected data by 1) qualitative methods (participatory observation, interviews with teachers, tutors, reflective analysis by the students), as well as by 2) quantitative methods (evaluation sheets for the perception of the learning process, questionnaires providing quantifiable data) to develop our research position. This way we implemented the guidelines for the relevance and quality of this piece of evidence-based educational research.

We re-defined and re-established our relationship between those universities participating in our research, the research teams and the public educational institutions participating in this research (kindergartens, schools, secondary schools) (Fazekas et al., 2015). In order to achieve its goals the scientific description of the new approach to learning, the criteria, and the new concept of Circular Learning was developed in professional dialogues. During these dialogues, we systematically considered the complexity of the phenomenon under examination in the most reflective way (OECD, 2007, 2015).

Of great value in our research is the fact that our basic goal is not to offer revelations but to create model communities of practice (Halász, 2017) in which educators, students, and researchers of learning processes work together on an equal, partnership basis to improve Circular Learning practices. At the centre of this thinking there is a serious analysis of the fundamental layers of children's learning (Gordon-Györi, 2008; Hattie, 2009; Halász, 2017). (Figure 1.) 


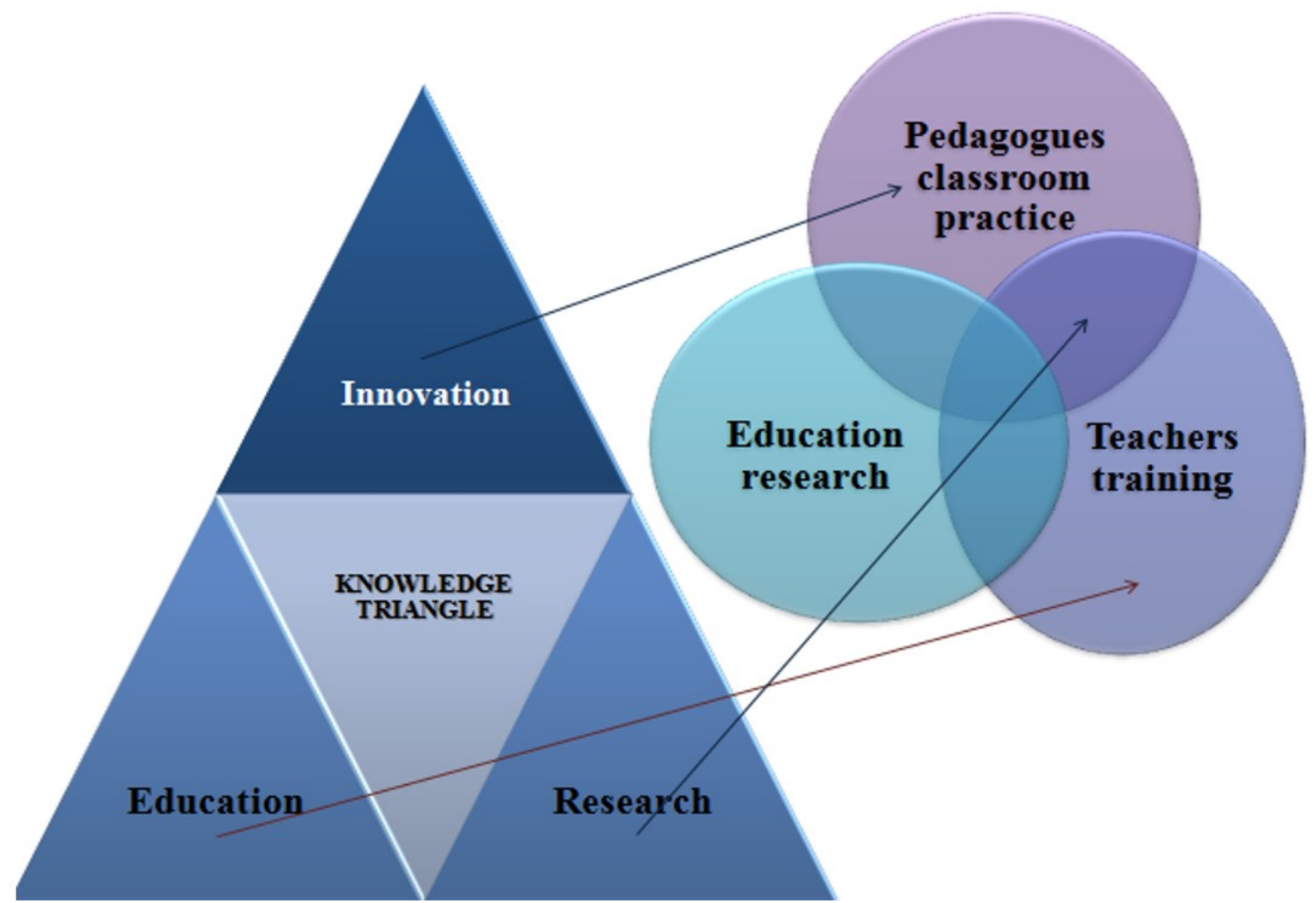

Figure 1. Model of the knowledge triangle or triple helix (Halász, 2017)

\section{Pedagogical goals and criteria of Circular Learning}

(1) Promoting student autonomy, (2) experiential learning: the teacher to provide opportunities for learners to learn from their own experiences, (3) a new partnership between teachers and students based on reciprocity, (4) creating innovative content and intensifying interpersonal relationships between students; and (5) the implementation of a constructive approach to learning at school (M. Nádasi, 1998; 2010a; 2010b; Brooks \& Brooks, 1993; Swan \& Hughes, 1997; Nahalka, 2003; Hunyadyné, 2003; Elias, 2010).

In the empirical part of the study we show how aspects of Circular Learning make learning more effective when these criteria are met in the course of implementation.

Our Circular Learning model incorporates a modern approach to project pedagogy (M. Nádasi, 2010b), because the purposes of education within this are always related to real-life social/ community, or personal life situations and real-life tasks.

Activities are always based on real-life questions and problems, in which learning through the child's selfactivity and their own experiences are essential. We considered it important to incorporate the relevant values in terms of psychology and the educational science view of the organization of cooperative learning (Slavin, 1980; 1987; 1990; Sobel, 1984; Johnson \& Johnson, 1994, 2009, 2013; Kagan, 2001; Aronson, 2019).

Therefore, in the learning situations that we created, we endeavoured to provide many opportunities for children to participate in parallel interactions in peer-education practice. International research has shown that the time available for a child's active interactions in normal classroom communication situations is often a matter of only minutes or seconds, therefore our goal was to provide an active role for students in Circular Learning (Sobel, 1984; Webb, 1989, 1995; Webb, 1989; Kagan, 2001) by creating steps in our cooperative learning approach. 
Beyond these factors it is the principles of constructive pedagogy that are most strongly reflected in the overall didactic process of the Circular Learning model employed in research (Nahalka, 2003; Swan \& Hughes, 1997; Vermunt, 1998; Brooks \& Brooks, 1993; Wilson \& Demetriou, 2007).

\section{The steps of Circular Learning}

In the first step of the method the class is divided into groups of four children (Figure 2.) We form consciously cooperating teams from these groups. Teams are given a colour or name, and we reinforce team identity development in different playful ways. Each child wears a badge with their name written on it.

1

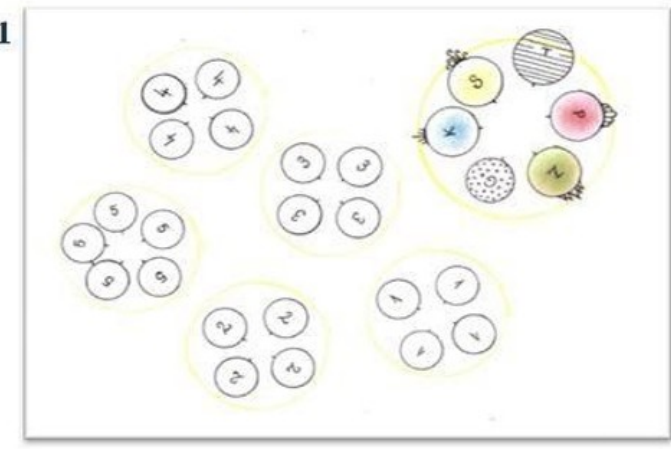

3

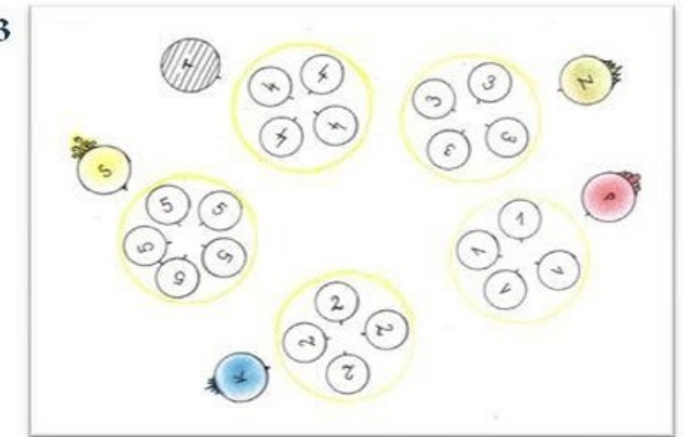

2

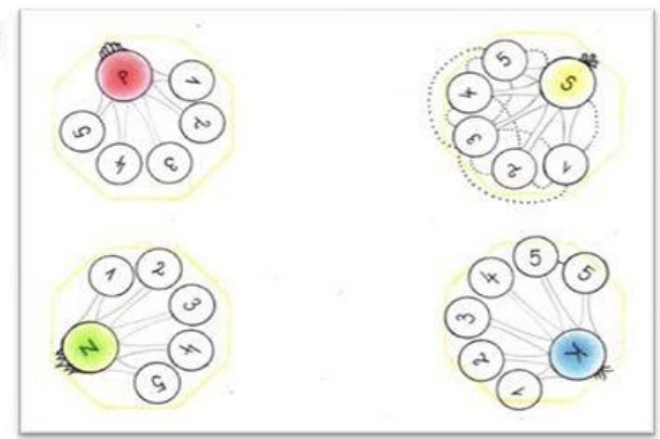

4

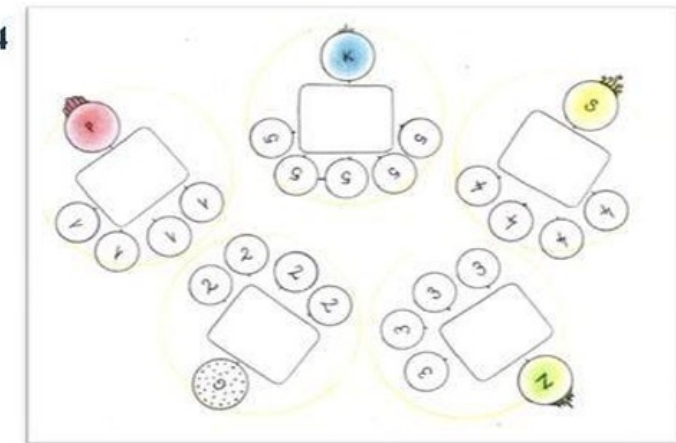

Figure 2. The implementation of Circular Learning

In step 2, all four participating students invite the children of another team of four (for example, by colour, number, or fancy name). The topic is divided into four parts, with each student teaching a part of the topic to their "expert" group. The number of children forming "expert" groups (learning a particular part of the topic from the student) is equal to the number of teams formed at the outset. In this phase, all four students teach their own group of "experts" in parallel for a given part of the topic. In this part of knowledge building, each child becomes an expert (Nahalka, 2003; Swan \& Hughes, 1997; Vermunt, 1998; Brooks \& Brooks, 1993; Wilson \& Demetriou, 2007). (Figure 3.) 


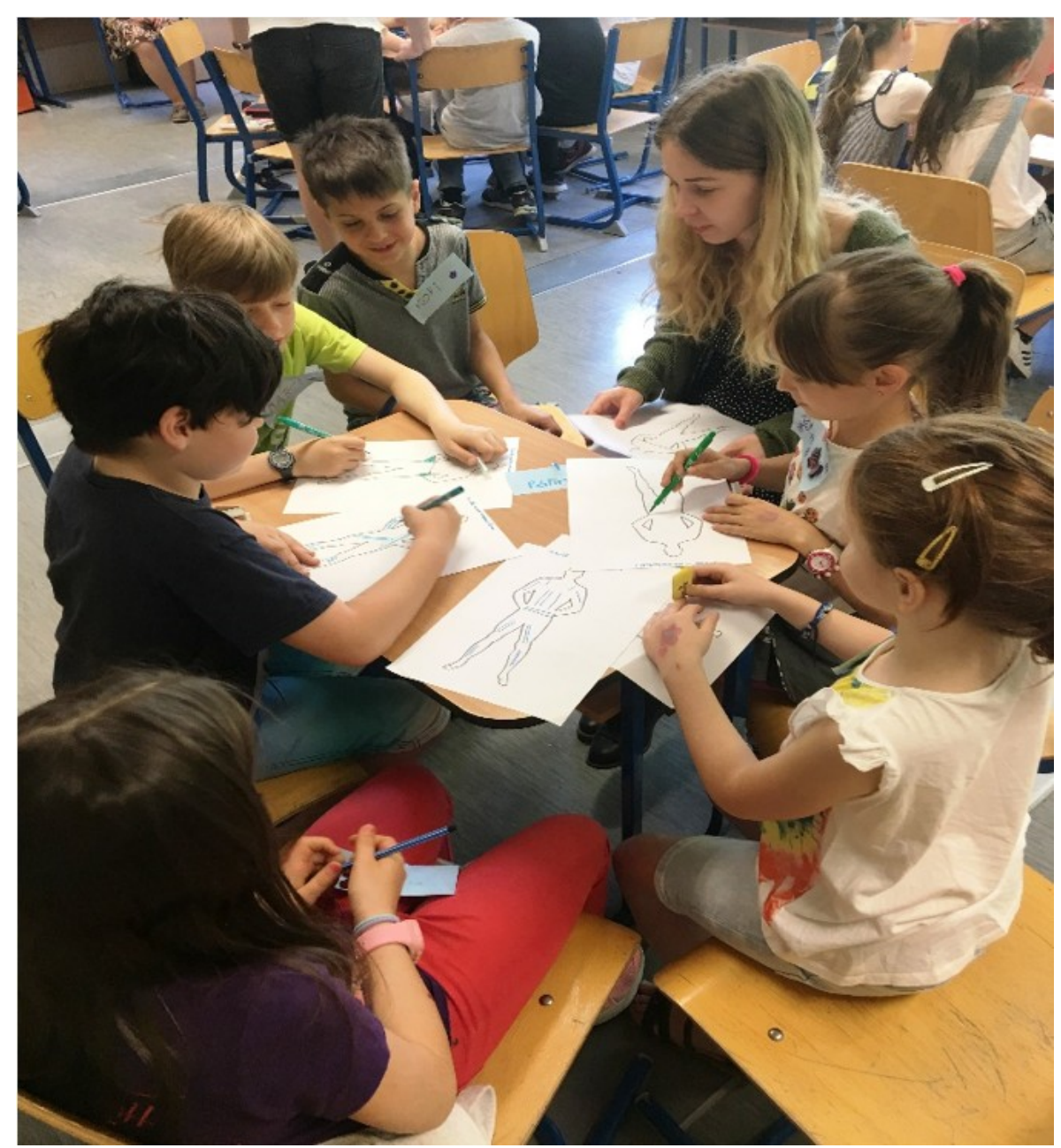

Figure 3. Circular Learning, step 2.

In step three, each child - as an expert in the part they have learned - goes back to their original small team (Slavin, 1980, 1990; Webb, Troper \& Fall, 1995; Webb, 1989; Aronson, 2019) and - as part of the knowledge construction process - teaches the others in the team everything learned in the previous step. The totality of the learning material is built up from the parts this way. (Figure 4.)

The adult supervisor can help the children's knowledge construction processes as a kind of facilitator through their active presence, asking questions, diverting the children, and ensuring the maintenance of the framework and rules. As far as possible they intervene as little as they can in the mutual teaching and learning phase. Let the children say in their own words what they have learnt about the topic and how they think about it. 


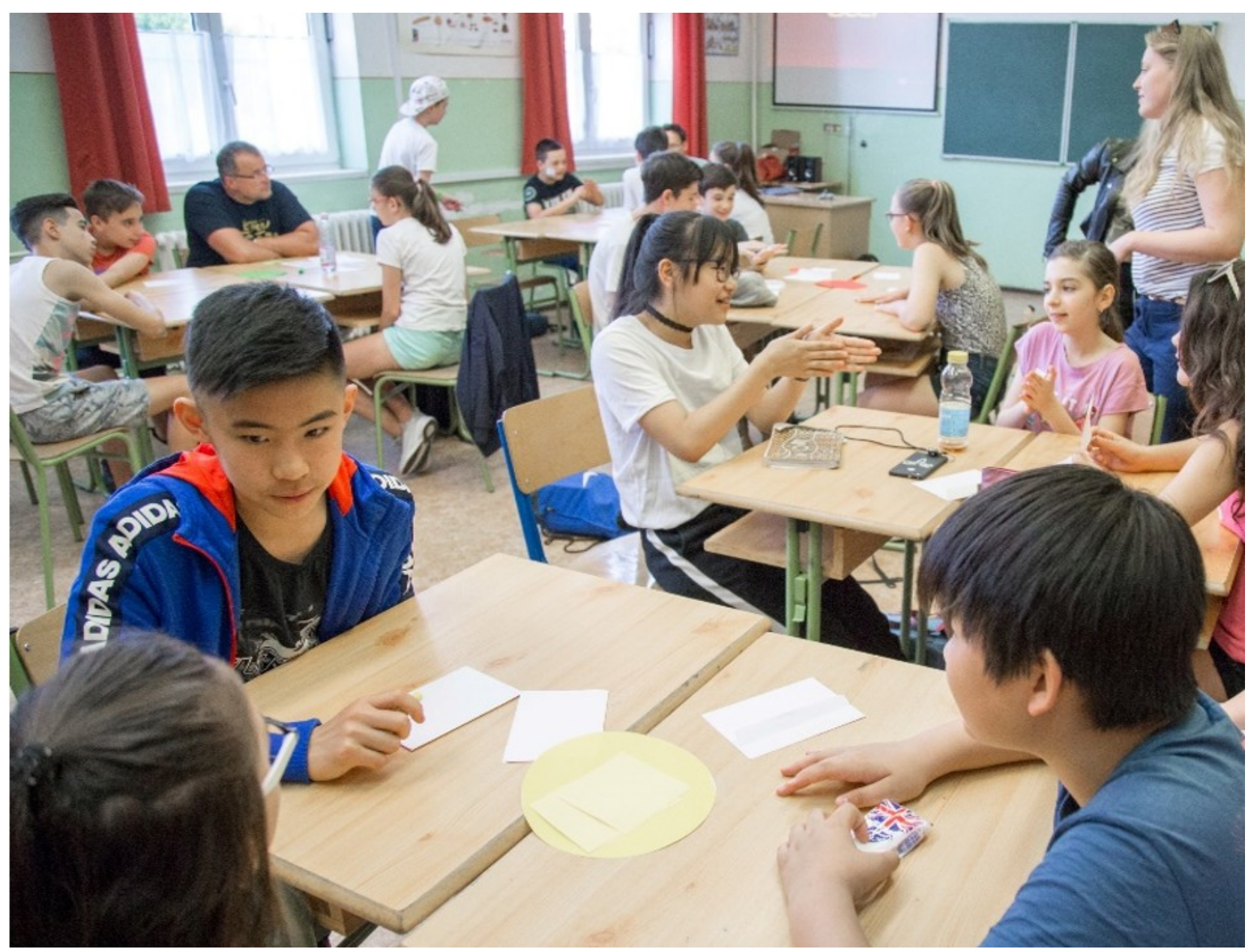

Figure 4. Circular Learning, step 3.

In the research model, after teaching each other in a circular way, children reflect on their own learning experiences, that is to say on the learning process, by means of an evaluation sheet. At the same time those adults who observed the children also fill in evaluation sheets reflecting on the learning processes of the children. The evaluation sheets basically assess the experiences of Circular Learning with the help of closedended statements, and at the same time require answers to open-ended questions, where they can also describe their suggestions to the research group. (Figure 4.)

In step four, the children work in their original groups. They perform exciting, playful tasks under the guidance of students, based on the freshly acquired knowledge. The groups walk around the students' desks and complete a set of tasks. In both Slavin's (1980) and Aronson's (2008) method at this stage it is essential to check individuals' knowledge through a worksheet in the classroom situation, with children receiving individual marks (Johnson, Johnson \& Stanne 2000). In Circular Learning, this stage differs fundamentally from these methods, both in terms of its pedagogical goals and the methodology of its implementation. By learning from each other, the children prepare for a common, interactive, playful summary activity based on their own experience, the main reward of which is the joy of the activities performed, the pleasure of participation, and the enjoyment of the learning process.

The steps of a learning event are defined, repeatable, and applicable to all ages. Immediately after learning, adult observers and the children are involved in the research evaluating the learning process and its efficiency. Establishing this learning situation give us the opportunity to study Circular Learning on an empirical basis. 
The learning organization model we have developed meets the four basic criteria for cooperative learning (Johnson \& Johnson, 1994, 2013; Kagan 2001), namely (1) constructive interdependence, (2) individual responsibility, (3) equal participation, and (4) parallel interactions.

We created a pedagogical model and a theoretical framework for Circular Learning that is flexible and adaptable in a variety of educational contexts (Kolosai, 2019). (Figure 5.)

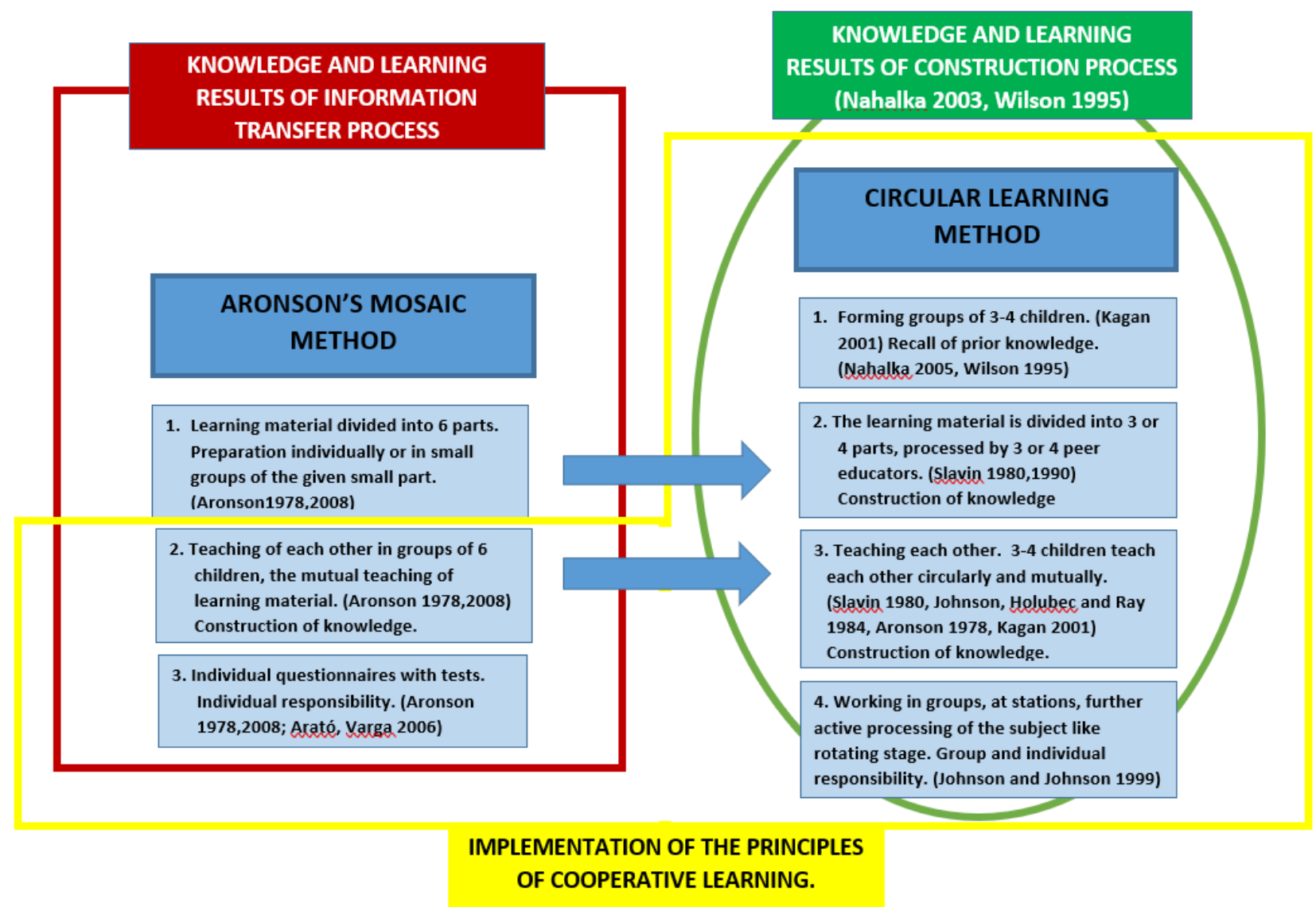

Figure 5. Steps of the model used in the research and comparison of the learning approach vs. Aronson's method. Source: Own creation

\section{Research Aims and Questions}

The aim of the research is to reduce the secondary disadvantages resulting from linguistic and cultural differences by rethinking the methods of learning and teaching.

That is to say, to diminish disparities arising from cultural and linguistic differences, to bring children closer to each other and to create equal opportunities for access to knowledge through the method of Circular Learning.

The research seeks answers to the following questions:

1. What aspects of the method do children in Circular Learning find effective?

2. Are there differences between the experiences of children in Circular Learning and those of the adults observing them? 
3. Which aspects of the Circular Learning method make it possible to compensate for cultural and linguistic differences? What factors can make peer-to-peer education effective from the children's perspective?

\section{The sample of research in the classroom experiment}

We studied the mutual learning and teaching by peers in spring 2018 when 284 children and 74 trained adult observers took part in the process of peer-learning. Children from first to eighth grade took part in Circular Learning. The adult observers' evaluations are available from all classes, the students from second to eighth grade filled out evaluation forms regarding their learning. We made efforts to involve children of heterogeneous socio-economic status in the research. We studied a complex pedagogical and educational process in 30 classes in 3 schools, in 4 times 45 -minute activities in each class, factors that reinforce the validity of the research and its results (Csíkos, 2012).

\section{Data collection}

We explored the children's experience in the experimental situation by using self-edited surveys consisting of 28 items including Likert scale statements and open questions ( $N=284$ children). ${ }^{2}$ For first and second grade children we created a simplified evaluation form of 11 extracts from the longer form. In the 11-itemshortened version we always used the shorter statements and deleted the control items.

At the same time adult observers ( $N=74$ adults) evaluated the learning process of the group based on predefined criteria in the Adult Assessment Forms. We compiled the statements of the child and adult evaluation forms so that they were suitable for comparing learning experiences.

\section{Data processing method}

(1) We processed the quantified answers of Children and Adults Assessment Forms by a) an R Statistical Program (R Core Team, Vienna, Austria, 2018) as well as b) an SPSS Statistical Program. Test groups were compared with a two-sample t-probe. Correlation calculations were performed using Spearman correlation coefficient at alpha $=0.05$ significance level, corrected by Holm's method for multiple hypothesis testing.

(2) We processed the answers of children and adults by qualitative content analysis. Content analysis used in qualitative methodology is a suitable scientific method for processing texts and narrative texts written by children, because these are personal documents in the sense of Allport (Ehmann, 2002) and our aim is to reveal subjective experiences of situations, attitudes, motivations and values (Szabolcs, 2001). They were classified during content analysis. The concept was to develop code matching where manifest and latent content ensures the reliability of the research. Considering the sequential-transformative model of the content analysis, our qualitative data are transformed, namely the data are qualitative in the process of formation but quantitative in terms of the final outcome (Ehmann, 2002). Where it makes sense, in the case of definitive categories quantitative analysis can be carried out with exact interpretation of the distribution of responses.

In each class we determined the fundamental code groups (Pataki, 2003) and categories (Szabolcs, 2001), and then a combined categorization system was created for the whole sample. We used the principle of

2. The research had a sharp focus on ethics and reflected rights-focused general and special ethical requirements. Ethical clearance (ETT TUKEB No18240-2/2017/EKU) included the consent of the parents of the children involved. 
comprehensive data handling, namely we did not skip any single datum, so our analysis includes deviant-case analysis (Szokolszky, 2004) for outliers. We made efforts to ensure these examples were handled as falsification tests and so did not decrease but rather increased the validity of our interpretations. We endeavoured to encode all non-typical cases. By doing so, we intended to increase the value of the qualitative research. Ensuring the validity of our research we applied the method of comprehensive data handling (Szabolcs, 2001; Sánta, 2006). The statements of our research refer to the entire sample: we tried to provide statements referring to all the children's answers.

\section{The results of the quantitative research}

During the quantitative processing of our data correlation analysis was carried out first on the processed research data, such as the responses of the children and adults. The results show that in statistical terms our data are strong, with many significant interactions between our statements and data. There is a significant correlation between claims that control each other, which was verified by appropriate statistical methods. Examination of our data in this way shows that the children from second to eighth grade read the statements carefully and responded consistently to the inverse formulation of the statements.

a. Results of a statistical analysis of Adult Assessment Forms for Circular Learning

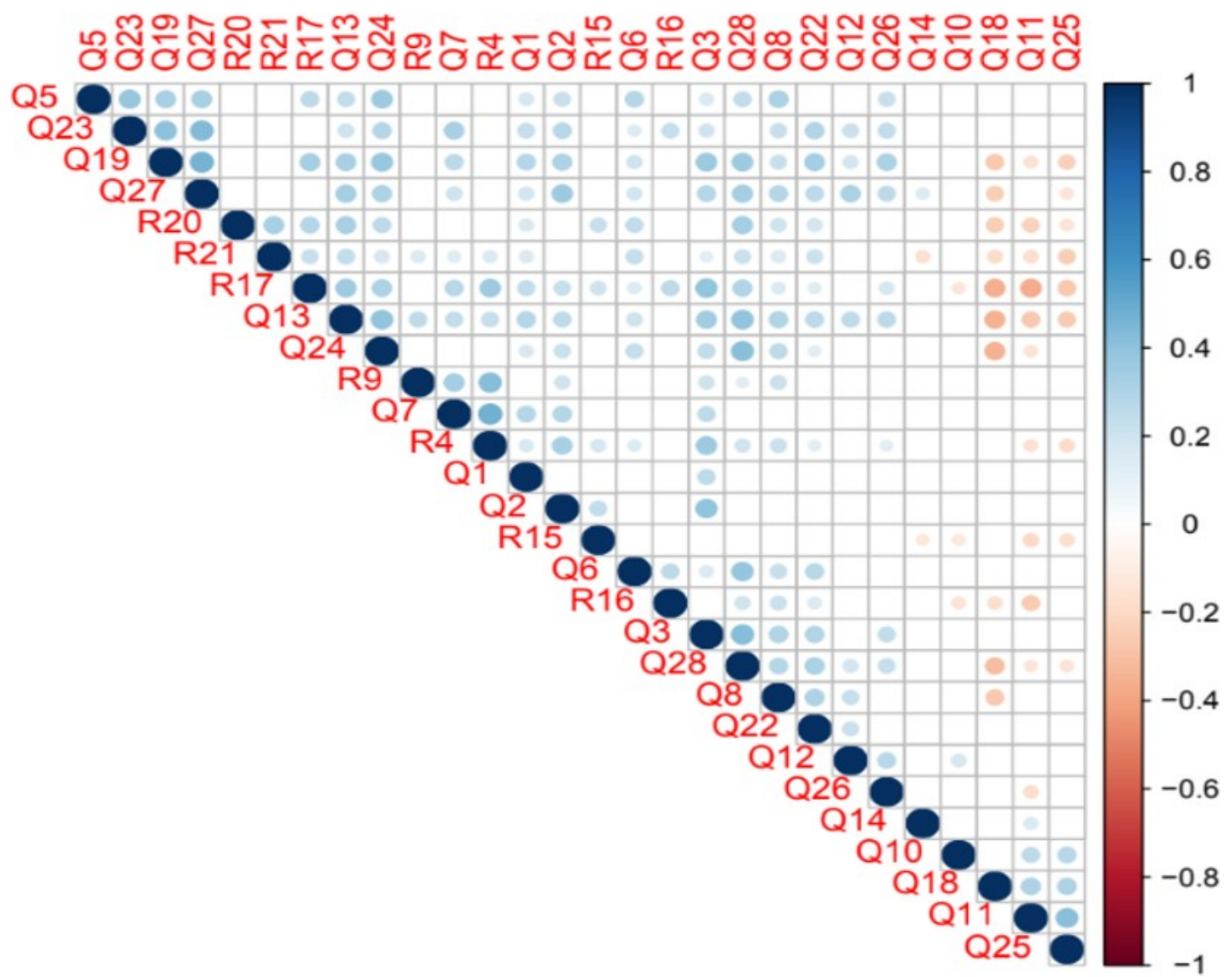

Figure 6. Correlation of adult observers reversed ( $N=74$ adults) - Blue spheres indicate positive correlation; red spheres indicate negative (inverse) correlation 
It is generally the case that in learning situations - according to adult observers - when students listened attentively to their peers, cooperation with the student team was realized. Attentiveness and inquisitiveness also correlate with the degree of the enjoyment of learning even in self-directed learning. In those teams where collaboration was not smooth, adult observers indicated that students should have been told more precisely what their task was: the values here show an inverse correlation. (Figure 6.)

b. Results of a statistical analysis of Student/Child Assessment Forms for Circular Learning

Significant correlation in the interpretation of children's responses can be found in a variety of items. The following relationships can be observed: Understanding ("I understand what my classmate taught me") was in correlation with self-reliance ("We were able to collaborate under adult supervision, independently"), as well as as with the adults' evaluation - also inquisitiveness. Interestingly, helping one another in learning correlated most highly with the enjoyment of learning.

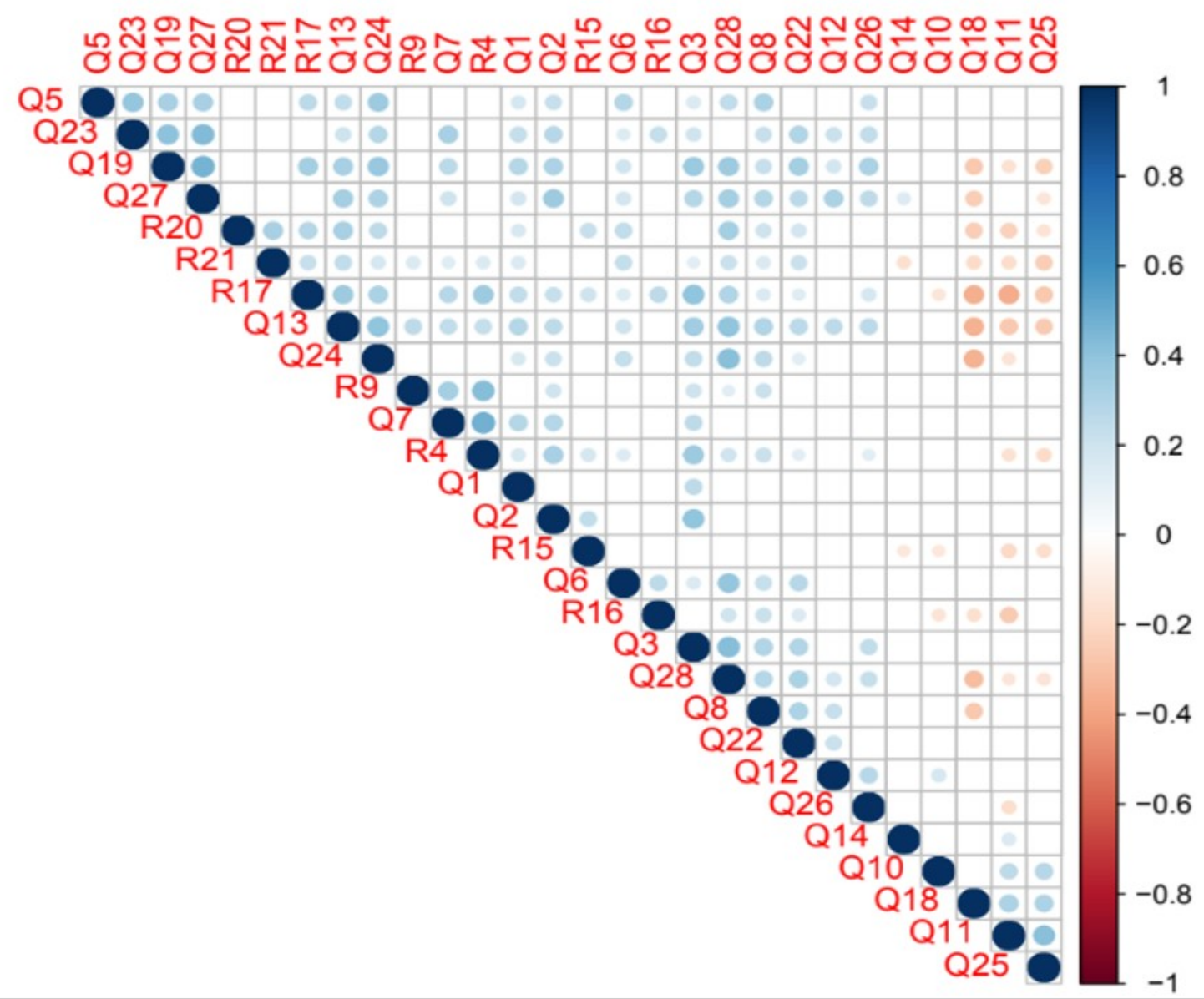

Figure 7. Correlation of Child/Student reversed ( $N=284$ children) - Blue spheres indicate positive correlation, red spheres indicate negative (inverse) correlation

In cases where children indicated that they hindered each other during the transfer of knowledge, the teacher repeatedly disciplined the students during the process of learning from each other. If we examine the average values of samples, statistically there were few instances of students hindering each other. 
Another important result was that understanding strongly correlated with the finding that students provided enough time for their classmates to present the topic they had learned and in which they became experts. (Figure 7.)

\section{Statistical interpretation of the relationships between the dimensions used in our modified research}

Dimensions and their correlations were examined based on the results of Likert scales. First, we examined with an appropriate statistical test the analysis of the dimensions of the data itself and the responses of the children and adults using the R statistical program (R Core Team, Vienna, Austria, 2018) and the SPSS statistical programs. Interestingly, the two statistical programs showed similar correlations between our data. (Figures 8. and 9.)

The statements are organized similarly into dimensions by both of to the two statistical programs. As shown by the diagrams the responses of the adult observers are organized into two separate groups. One group contains negative statements about the learning situation (for example: "The children were thinking about inappropriate topics. They talked about something else during the exercise"); the other group contains statements describing the learning process in a supportive way ("The students were very attentive to each other. The student experts on the subject matter took their task seriously.") The deeper analysis of the research data was in harmony with these early results. It was significant that the adult observers found that the children in the research situation were able to transfer their knowledge, listened to each other, and listened to their quieter peers also. The correlations are shown in Figures 8. and 9.: the spontaneous sorting into dimensions of statement values provided validity for the two-samples t-probe, while also allowing for the possibility of further analysis of the data.

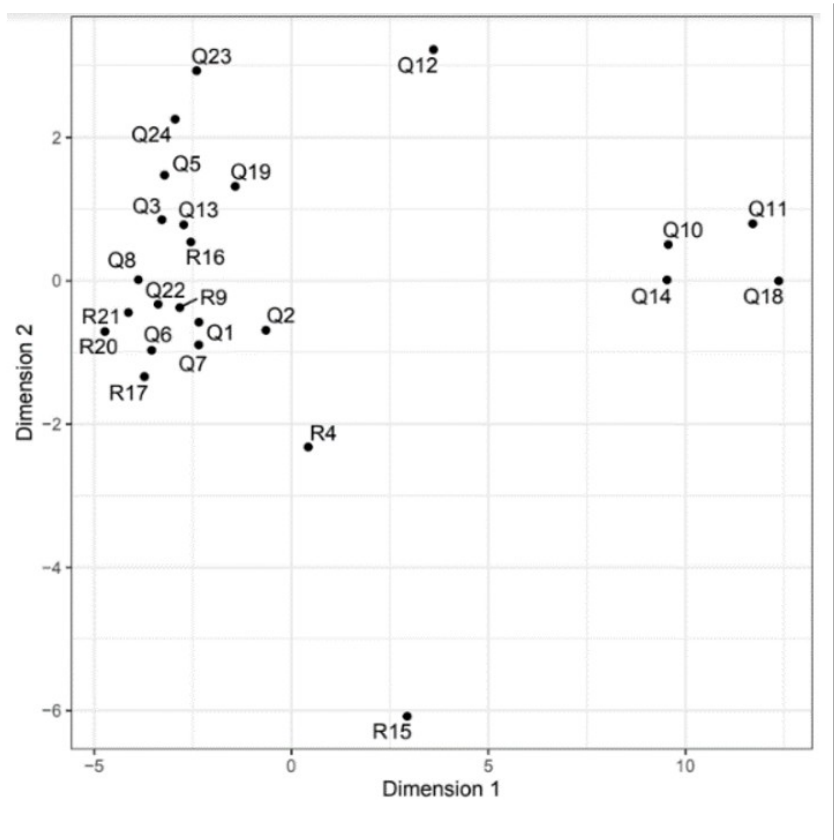

Figure 8. R Statistical Program $R$ Core Team, Vienna

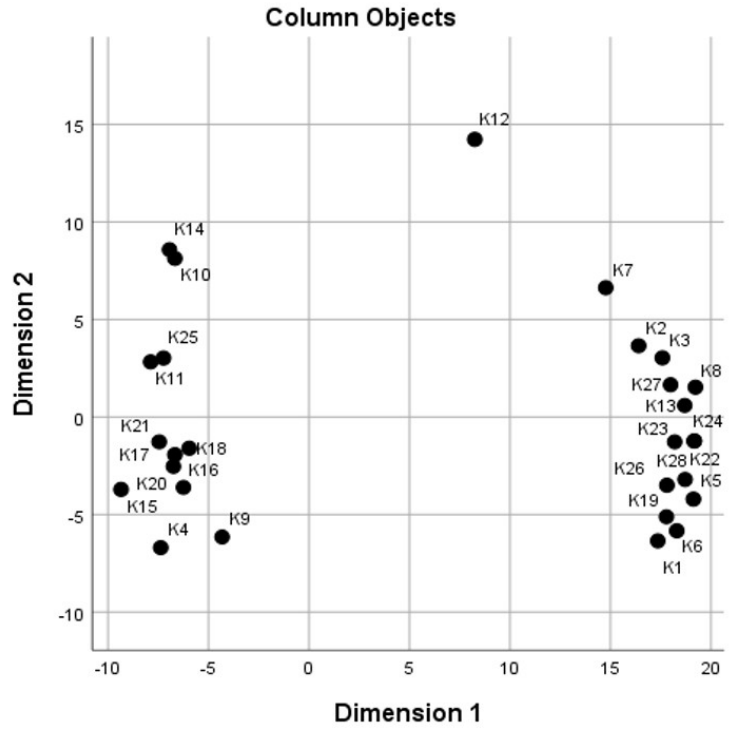

Figure 9. SPPS 
We also created the dimensions from related content items and then checked how our "new" dimensions correlated with each other on the basis of the statistical values of the sample. The items can be sorted into the following dimensions: Discipline, Curiosity, Positive Emotions, Responsibility, Collaboration, Learning efficiency (Learning effectiveness). We created the same dimensions for statements about the children, with the addition of the Importance of my knowledge dimension. We selected four items for each dimension.

\section{Analysing the correlation of dimensions describing the learning process in adult observers}

In the Responsibility dimension (for example: "We took our task seriously"), the reinforcement of responsibility is one of the objectives of the research program, there is a strong synergy with the Collaboration dimension in the children (for example: We were able to work together without argument). The values of Inquisitiveness dimension (for example: "We listened to each other inquisitively." "We asked each other about the topic."), too, show a strong correlation with the Cooperation dimension (for example: "The quieter students also had the opportunity to say what they could.") (Figure 10.)

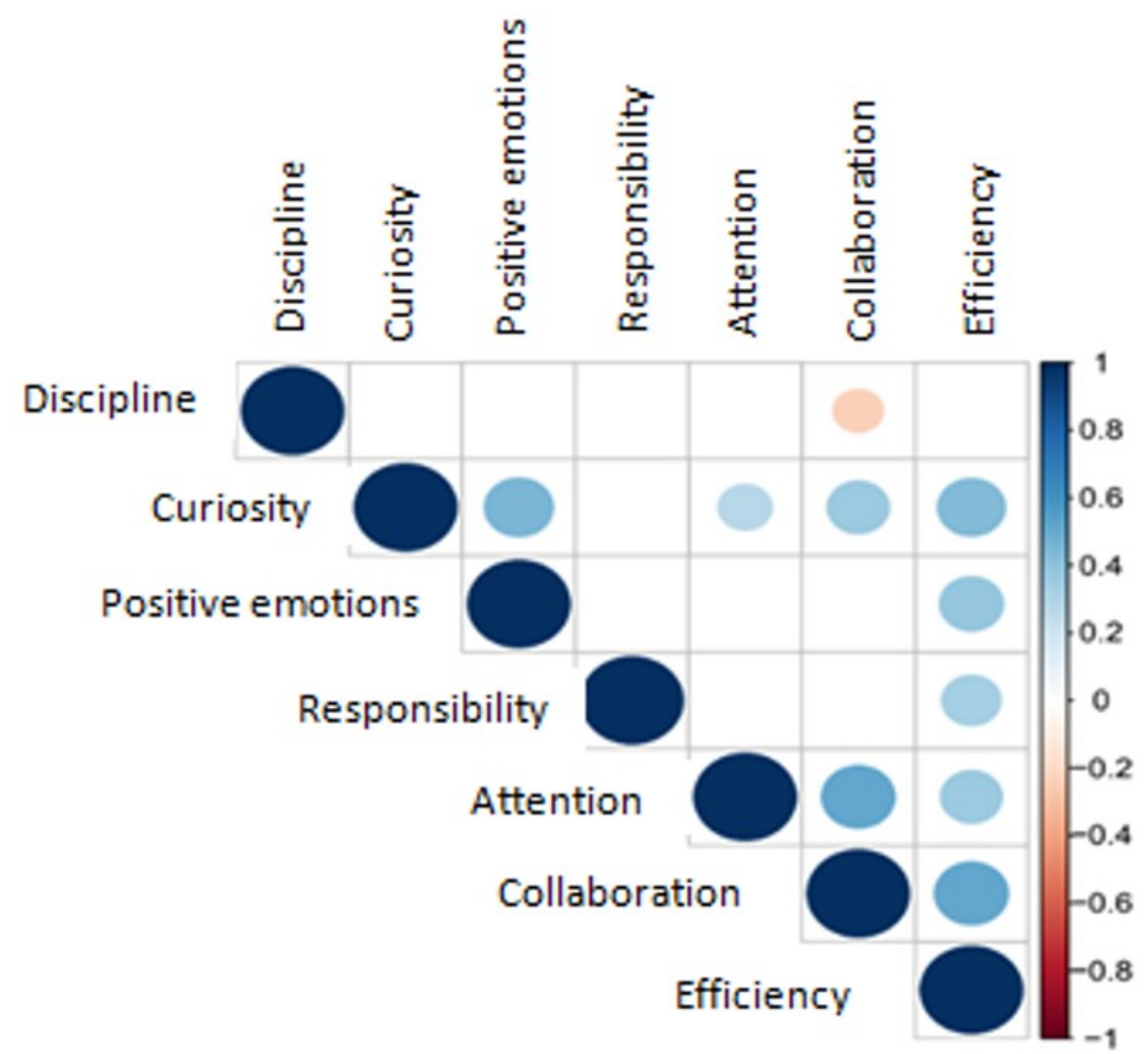

Figure 10. Correlation of dimensions describing the educational aspects of the learning process of adult observers. Blue spheres indicate positive correlation, red spheres indicate negative (inverse) correlation 
The analysis of the dimensions shows that the items of the Collaboration dimension were in the strongest correlation with the items of Understanding of the learning material. Our research results provide a plastic picture of how to enhance collaboration through appropriate pedagogical approaches (for instance, by arousing curiosity) and can contribute to greater understanding and responsibility. (Figure 10.)

\section{Analysing the correlation of dimensions describing the learning process of students}

The Discipline Dimension shows negative correlation with the Collaboration Dimension in adults. (Figure 10.) In case of the children, the Discipline Dimension shows also negative correlation with Collaboration as well as with the Attention and Understanding Dimensions. (Figure 11.)

The Curiosity Dimension in adults shows the strongest correlation with Efficiency, but also strong correlation with the Positive emotions, Attention and Collaboration dimensions (Figure 10.) At the same time, we obtained interesting results in the case of the children, in that the Curiosity Dimensions shows positive correlation with the Importance of my knowledge, Responsibility, Attention and Positive emotions dimensions. (Figure 11.)

Our results suggest that the controlling presence of an adult might have a negative influence on the efficiency of attention and understanding, while these general psychological aspects are essential for learning. At the same time, discipline might have a negative influence on the effectiveness of cooperation among children.

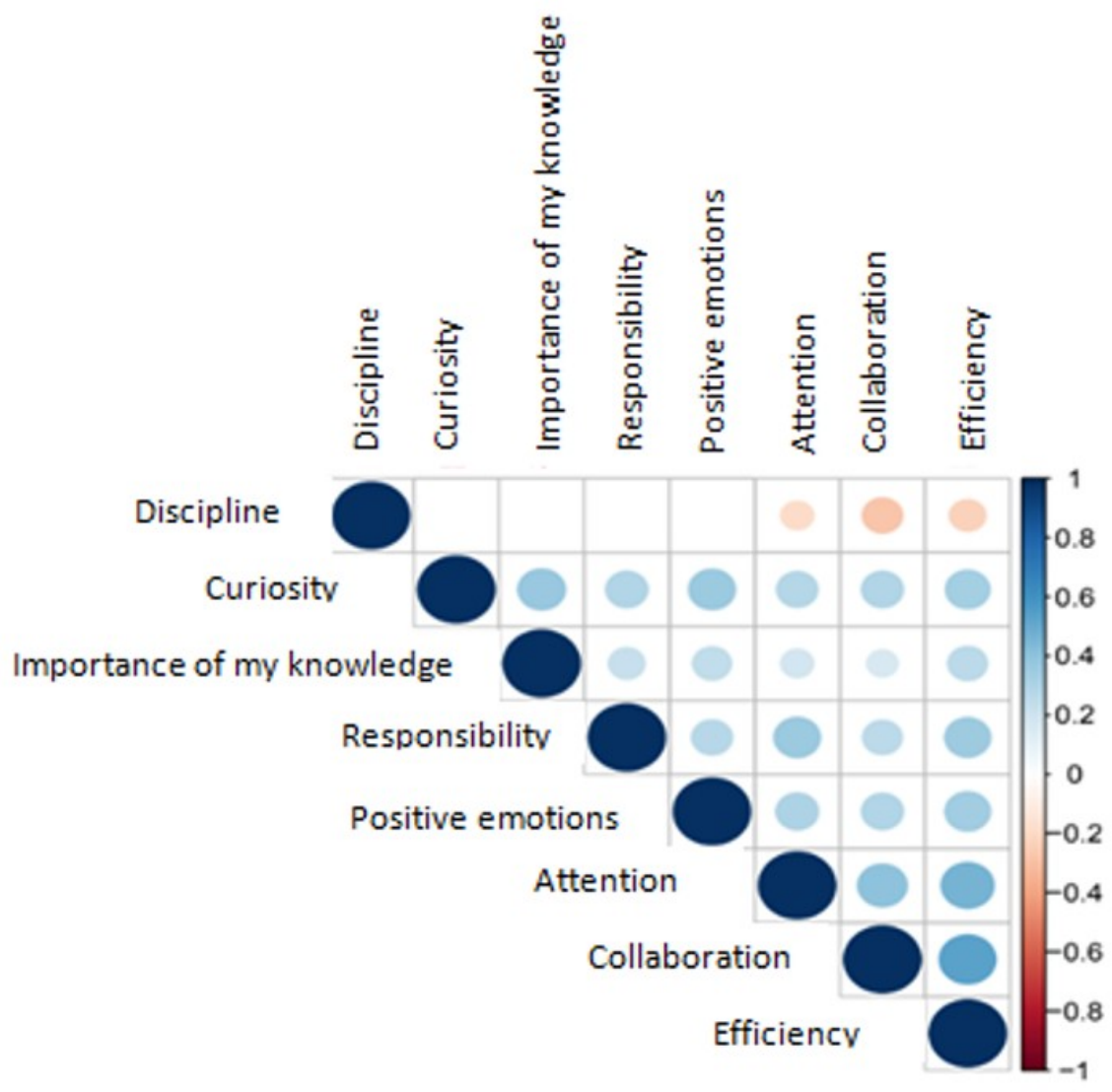

Figure 11. Correlation of dimensions describing the educational aspects of the learning process of children. Blue spheres indicate positive correlation, red spheres indicate negative (inverse) correlation 


\section{Results of responses from disadvantaged versus non-disadvantaged children}

In our research, children defined as disadvantaged tend to say that they talked about the subject, whereas non-disadvantaged children considered that they did not always talk about the subject but talked about other topics. In this one respect there were differences in the two samples t-probe $(p=0,1560$; corrected $p=0,0727)$. It might follow that this type of learning tends to attract the attention of disadvantaged students more than non-disadvantaged students. More precisely it captures the attention of both groups because the difference is not significant, but it is interesting that disadvantaged learners are more likely to talk only about the given topic.

\section{Statistical differences of responses of adults and children}

The strongest significant difference was shown in the learning experiences of adult observers and the children "We expect assistance from the adults", or "They expect assistance from the adults": the students perceived the learning situation as not expecting help from the adults, whereas the adults perceived the students as waiting for the adults to assist. ( $p=0,0004$; corrected $p=0,0106$ )

The truth is even more subtle if we look at the results of the group averages. Because both groups were more likely to find that students did not expect assistance from adults, the difference in their experience was significant and showed the tendency described above. In the 20th statement "Conflict developed between the students during the transfer of knowledge" there is also a significant difference between the assessment of adults and students, even in the corrected $p$ value. The adults felt that a conflict had arisen, while the students did not perceive any conflicts during the learning process ( $p=0,0092$; corrected $p=0,0727)$. At the same time, by examining the group averages we also found that both groups perceived that there were no conflicts and were able to carry out each other's teaching smoothly. We found another inconsistency in "They asked each other about the topic": students felt that they asked each other in connection with the topic, while according to the adult observers the children did not.

A highly significant result is that the evaluation of the item "They were able to formulate and tell their peers what they became experts at" is the same for both adults and children. Fundamental result of our research was that according to both students and adult observers, children were able to teach each other in a circular and mutual way through the learning steps we have developed.

In the case of item 7, "They talked about the topic", the answers are distinct but not significantly different. The adults' experience was rather that students did not talk about the topic. This difference is very important because it shows the existence of different interpretations of what learning is, which are essentially the results of different cultural and generational differences. According to the students these differences in the learning processes did not reduce but rather increased the effectiveness of learning; for instance, in their opinion the conversation and storytelling made learning more productive.

\section{Results of the qualitative research}

\section{Qualitative content analysis of textual response of students and adult observers}

The students participating in the research also answered open-ended questions. We asked them why, in their experience, it was good to learn from their classmates and to teach each other in a circular way. The aspects of 
learning from an adult, a teacher, are experienced on a daily basis by the children involved in the research, allowing them to distinguish between the two modes of learning.

The textual responses of each class were systematically analysed, categorized, and subsumed into categories. In summary, it was possible to set of eight broad categories; of course, these are closely related, but they appeared separately in the responses of children. A very exciting result is that most of the children/students suggested that they learned more, learned better, learned more quickly, and more efficiently from other students, and they described the aspects of this efficiency they experienced. These aspects can be sorted into the following main categories: 1 . Benefits relating to childhood, to the children's shared culture; 2 . the benefits of a shared perspective; 3 . benefits of working in a team or group; 4 . positive effects on memory, 5. a positive effect on attention; 6. improved understanding; 7. the positive emotional environment that facilitates learning, as well as the fact, that 8 . it was interesting to learn from peers. (Figure 12.)

\section{CIRCULAR LEARNING}

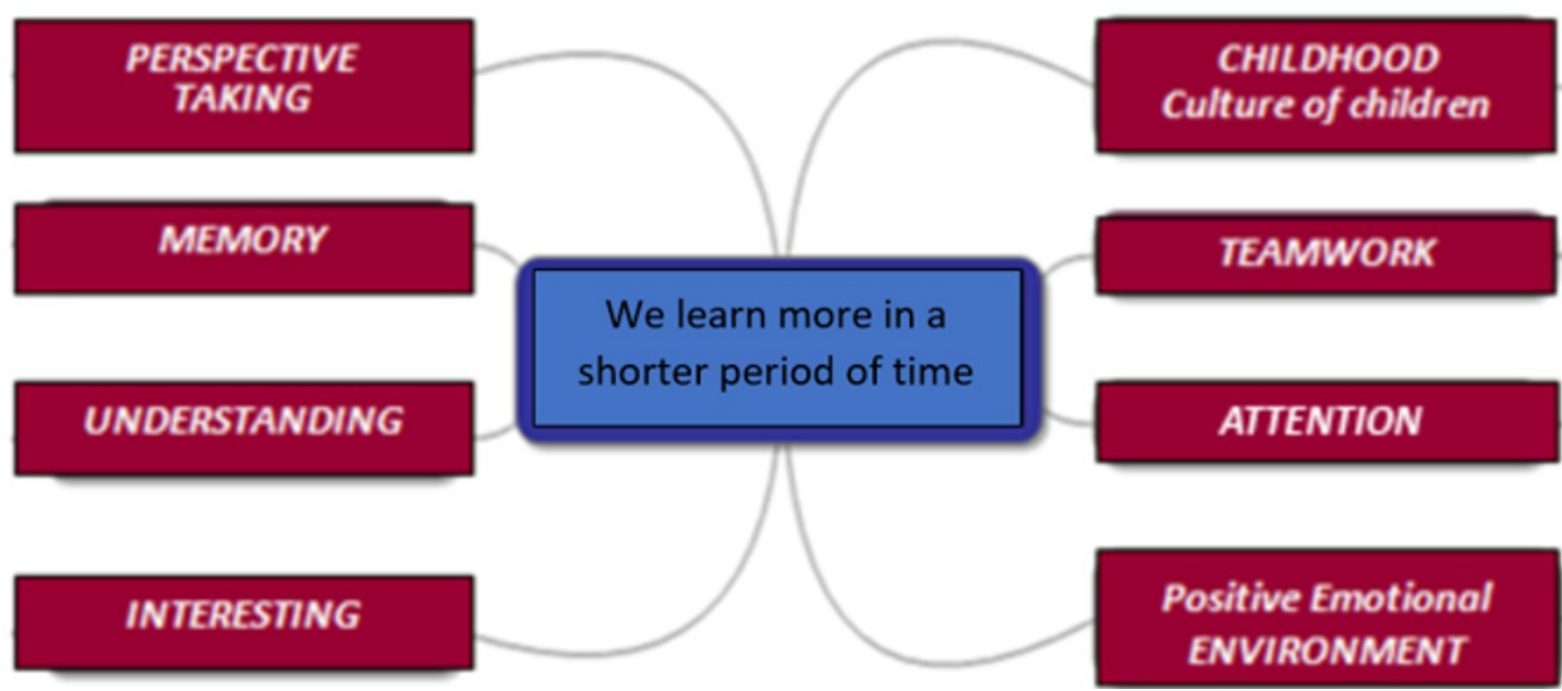

Figure 12. Why the Circular Learning is an effective educational method. The entire sample of 8 main categories developed by students on the effectiveness of peer education

\section{Summary of our research results}

By adapting and re-thinking the Aronson mosaic method, our research team has developed an innovative circular classroom learning model that creates opportunities for the validation of different aspects of teaching.

The learning procedures used in our research model create opportunities for children from different cultures, different mother tongues and very different socio-economic statuses (diversity) to learn, have equal access to knowledge (equity), cooperate with each other and have equality as well as mutual understanding (sustainability).

Our learning model can harmonize the social needs of social integration, opportunity creation and social sustainability (Sugai \& Horner, 2006; Knausz, 2017; Halász, 2017; Gordon-Győri, 2017), as well as the cognitive 
goals of teaching (e.g. applicable knowledge) (Márkus, M. Pintér \& Trentinné Benkő, 2017). We consider the aspect described by children to be important: while teaching each other, learning in a "circular" way from each other, they can learn how their classmates interpret a given phenomenon and fit into their perspective. Through their peers' personal stories, they can get to know them and the topic being studied at the same time. ("Because you can see the world from the perspective of others") Currently, in Hungary and worldwide, it is of great importance to develop the ability of children to integrate into another person's way of thinking. Sharing the perspective of others, in addition to the effectiveness of learning, is a significant factor in developing empathy.

The results of the Likert scale used in the evaluation sheets of the research showed exciting correlations.

During the examinations of the dimensions, it appeared that the items in the Collaboration dimension showed the strongest correlation with the items related to the Understanding of the material studied. Our research results provide a plastic picture of how to enhance collaboration through appropriate pedagogical approaches (for instance, by arousing curiosity) and can contribute to greater understanding and responsibility.

Our results suggest that the controlling presence of an adult might have a negative influence on the efficiency of attention and understanding, general psychological aspects essential for learning. At the same time, discipline might have a negative influence on the effectiveness of cooperation between children.

A fundamental result of our research was that according to both students and the adult observers, the children were able to teach each other in a circular and mutual way through the learning steps we have developed.

According to the students these differences in the learning processes did not reduce but rather increased the effectiveness of learning; for instance, in their opinion the conversation and storytelling made learning more productive.

The students participating in the research also answered open-ended questions. We asked them why, in their experience, it was good to learn from their classmates and to teach each other in the circular method. The aspects of learning from an adult - a teacher - are experienced on a daily basis by the children involved in the research $(\mathrm{N}=284)$, allowing them to distinguish between the two modes of learning. Based on the content analysis of the narratives of students regarding the Circular Learning situation (learning from other students, from a peer) we can say that most of the students stated that they learned more from their peers, learned better, learned more quickly and more efficiently, and later described the aspects of this efficiency that they experienced. These aspects, as described by the students, present the main categories and the educational aspects of the effectiveness of Circular Learning. The 7-to-15-year-old students emphasised several items regarding the benefits of learning from other students. The research sample was compiled so that there were linguistic and cultural differences between the children, with children of different mother tongues meeting in the classes. Yet children highlighted that in this learning situation they understood the explanations of their classmates better than the adults' responses. Due to the benefits of perspective-sharing, they have the opportunity to explore things from the perspective of the other child, to get to know the other child's stories, which - according to the students - help to lodge the learning material in their memory, to get to know and accept each other better (Osher, 2016; Knausz, 2017). According to research, the possibility of perspectivesharing is a fundamental tool for developing empathy. The benefits of teamwork promote collaboration and cooperation in the classroom. These students emphasized the positive effects of Circular Learning on memory, which result from an unforgettable situation on the one hand and, on the other, the personal form of learning that enhances their autobiographical memory. In their narratives, the children described the positive emotional environment, the humour, the pleasant atmosphere that facilitated learning, and the fact that learning from 
their peers was interesting and exciting. Finally, students highlighted the positive effects of peer education on the attention-span as well as on the improved understanding of the material to be mastered resulting from the positive aspects listed above.

Novelty of our research is that we developed the Circular Learning method what was described based on empirical data and research facts. Based on empirical research, our study presents the factors (aspects) describing the effectiveness of active learning among children.

Being involved in a peer's perspective is an essential element of empathy, which is actively shaped when children teach each other directly. In addition to the writing-reading content conveyed during teaching, the ways in which learning created in the classroom is organized allow them to pay attention to a peer with whom they would otherwise have less interaction (Wilson, 1996; Wilson \& Demetriou, 2007). According to our evidence-based research when children experience that they can learn from each other, it actively contributes to the development of empathy skills.

This is a current societal need in the linguistic and cultural diversity that it has become an important task for the school to take an active role in understanding each other (Knausz, 2017; Sugai \& Horner, 2006). This applies to adults as well. In the case of children of different mother tongue and different cultures, it is important that the children have the competence and (even) the need to fit into the point of view from which their peer, another child, observes the world. Getting to know each other always brings us closer to understanding each other.

Our important result is that the effectiveness of children's Circular Learning from each other can be best understood by taking into account the experience of children, by listening to the "voices of children". 


\section{References}

1. Arató, F. (2010a). Egy lehetséges általános kooperatív modell lehetőségéról. Iskolakultúra, 20(1), 106116.

2. Arató, F. (2010b). A kooperatív tanulásszervezés paradigmatikus jellege. In Kozma, T. \& Perjés, I. (Eds.), Új Kutatások a neveléstudományokban. Törekvések és Lehetőségek a 21. század elején (pp. 11-22). Budapest: Magyar Tudományos Akadémia Pedagógiai Bizottsága, ELTE Eötvös Kiadó.

3. Aronson, E. \& Aronson, J. (2019). Readings About The Social Animal. Worth Publishers.

4. Brooks, J.G., \& Brooks, M.G. (1993). In Search of Understanding: The Case for Constructivist Classrooms. Alexandria: Association for Supervision and Curriculum Development.

5. Csíkos, Cs. (2012). Pedagógiai Kísérletek Kutatásmódszertana. Budapest: Gondolat Kiadó Kör.

6. Ehmann, B. (2002). A szöveg mélyén - A pszichológiai tartalomelemzés. Budapest: Új Mandátum.

7. Elias, M., J. (2010). Sustainability of social-emotional learning and related programs: Lessons from a field study. International Journal of Emotional Education, 2(1), 17-33.

8. Gordon Győry, J. (2008). Tanórakutatás. Budapest: Gondolat Kiadó.

9. Gordon Győry, J. (2017). Tudás és esélyteremtő modellek a nemzetközi térben. In Hunyady, Gy., Csapó, B., Pusztai, G. \& Szivák, J. (2017, Eds.), Az oktatás korproblémái (pp. 79-92). Budapest: Eötvös Kiadó.

10. Garcia, C., Rivera, N. \& Greenfield, Patricia M. (2015). The decline of cooperation, the rise of competition: developmental effects of long-term social change in Mexico. International Journal of Psychology, 50(1), 6-11. https://doi.org/10.1002/ijop.12120

11. Halász, G. \& Fazekas, Á. (2016). Az oktatási innovációk világa. A tanulás szervezést érintő innovációk specifikumainak áttekintése. In Ugrai, J. \&Varga, A. (2016). Tanulmányok a pedagógiai innováció támogatásának lehetőségeiről. Budapest: Oktatáskutató és Fejlesztő Intézet.

12. Halász, G. (2017). A neveléstudományi kutatások globális trendjei, különös tekintettel a kutatás, az iskolai gyakorlat és a szakpolitikák kapcsolatára. In Hunyady, Gy., Csapó, B., Pusztai, G. \& Szivák, J. (Eds.), Az oktatáskorproblémái. Budapest: ELTE Eötvös Kiadó. 21-41.

13. Hattie, J. (2009). Visible Learning. A synthesis of over 800 meta-analyses relating to achievement. London: Routledge.

14. Hunyadyné, Gy. (2003). Bevezető Egy Rendhagyó (tantárgy)pedagógiai jegyzethez. In Differenciált Fejlesztés - Kooperatív Tanulás (pp. 7-11). Budapest: Eötvös Loránd Tudományegyetem Tanító- és Óvóképző Kar.

15. Johnson, D. W. \& Johnson, R. T. (1994). Learning together and alone: Cooperative, competitive, and individualistic learning. Boston: Allyn \& Bacon.

16. Johnson, D. W., Johnson, R. T. \& Stanne, M. B. (2000). Cooperative Learning Methods: A Meta-Analysis. Minnesota: University of Minnesota.

17. Johnson, D. W. \& Johnson, R. T. (2009). Joining together: Group theory and group skills. Boston: Allyn \& Bacon.

18. Johnson, D. W., \& Johnson, R. T. (2013). The impact of cooperative, competitive, and individualistic learning environments on achievement. In J. Hattie \& E. Anderman (Eds.), International handbook of student achievement (pp. 372-374). New York: Routledge.

19. Kagan, S. \& Kagan, M. (2009). Kagan Cooperative Learning. San Clemente: Kagan Publishing.

20. Knausz, I. (2017). Múveltségkép Az Ezredforduló Után. In Hunyady, Gy., Csapó, B., Pusztai, G. \& Szivák, J. (Eds.), Az oktatás korproblémái (pp. 58-68). Budapest: ELTE Eötvös Kiadó.

21. Kolosai, N. (2019). A kortársoktatás neveléstudományi fogalmi keretei. In. Feith, H. \& Falus, A. (Eds.), Egészségfejlesztés és nevelés (pp. 108-114). Budapest: Akadémiai Kiadó.

https://doi.org/10.1556/9789634544456 
22. Márkus, É., M. Pintér, T. \& Trentinné Benkő, É. (2017). Jó gyakorlatok a korai idegen nyelvi fejlesztésben és pedagógusképzésben: Oktatás, kutatás, innováció. Budapest: ELTE Tanító- és Óvóképző Kar.

23. M. Nádasi, M. (1998). Az oktatás szervezési módjai és munkaformái. In Falus, I. (Ed.), Didaktika Elméleti alapok a tanítás tanulásához (pp. 368-391). Budapest: Nemzeti Tankönyvkiadó.

24. M. Nádasi M. (2010a). Adaptív nevelés és oktatás. Budapest: Géniusz Könyvek.

25. M. Nádasi, M. (2010b). A projektoktatás elmélete és gyakorlata. Budapest: Géniusz Könyvek.

26. Nahalka, I. (1997). Konstruktív pedagógia - Egy új paradigma a láthatáron. Iskolakultúra, 7(4). 3-20.

27. Nahalka, I. (2003). Hogyan alakul ki a tudás a gyermekben? Konstruktivizmus és pedagógia. Budapest: Nemzedékek Tudása Tankönyvkiadó.

28. OECD (2010). The OECD Innovation Strategy Getting A Head Start On Tomorrow. Paris: OECD Publishing.

29. OECD (2014). Measuring Innovation in Education: A New Perspective, Educational Research and Innovation. Paris: OECD Publishing.

30. Osher, D., Kidron, Y., Brackett, M., Dymnicki, A., Jones, S. P. \& Weissberg, R. (2016). Advancing the Science and Practice of Social and Emotional Learning: Looking Back and Moving Forward. Review of Research in Education, 41(17), 644-681. http://dx.doi.org/10.3102/0091732X16673595

31. Pataki, F. (2003). Együttes élmény - Kollektív emlékezet. Magyar Tudomány, 162(1), 26-35.

32. Popper, K. R. (1997). A tudományos kutatás logikája. Budapest: Európa Kiadó.

33. Slavin, R. E. (1980). Using Student Team Learning. Baltimore: Johns Hopkins University.

34. Slavin, R. E. (1987). A Theory of School and Classroom Organization. Educational Psychologist, 36(22), 89-108. https://doi.org/10.1207/s15326985ep2202_1

35. Slavin, R. E. (1990). Achievement Effects of Ability Grouping in Secondary Schools: A Best Evidence Synthesis. Review of Educational Research, 60(3), 471-499. https://doi.org/10.3102\%2F00346543060003471

36. Sobel, J. (1984). Everybody wins: 393 Non-Competitive Games for Young Children. New York: Walker and Co.

37. Sugai, G. \& Horner, R. R. (2006). A promising approach for expanding and sustaining school-wide positive behaviour support. School Psychology Review, 35(2), 245-259. https://doi.org/10.1080/02796015.2006.12087989

38. Swan, G. \& Hughes, B. (1997). Constructivism: Definition and Implications for Implementation. Tempe, Arizona: Maricopa Community College District.

39. Szokolszky, Á. (2004, Ed.). Kutatómunka a pszichológiában. Budapest: Osiris Kiadó.

40. Szabolcs, É. (2001). Kvalitativ Kutatási Metodológia a pedagógiában. Budapest: Műszaki Könyvkiadó.

41. Vermunt, J. R. (1998). Regulation of constructive learning. British Journal of Educational Psychology, 68(2), 149-171. https://doi.org/10.1111/J.2044-8279.1998.TB01281.X

42. Webb, N. M. (1989), Peer interaction and learning in small groups. International Journal of Educational Research, 58(13), 21-39. https://doi.org/10.1016/0883-0355(89)90014-1

43. Webb, N. M., Troper, J. D. \& Fall, R. (1995). Constructive Activity and Learning in Collaborative Small Groups. Journal of Educational Psychology, 87(3), 406-423. https://psycnet.apa.org/doi/10.1037/00220663.87.3.406

44. Wilson, B. (1996, Ed.). Constructivist Learning Environments: Case Studies in Instructional Design. New York: Educational Technologies Publications Englewood Cliffs. https://lib.ugent.be/catalog/rug01:002029648

45. Wilson, E. \& Demetriou, H. (2007). New teacher learning: substantive knowledge and contextual factors. The Curriculum Journal, 18(3), 213-229. https://doi.org/10.1080/09585170701589710 


\section{Kultúrák és nyelvek találkozása az osztályteremben - Aronson módszerének újragondolása}

A kulturális és nyelvi különbségek öntudatlanul befolyásolják az iskolai élet szereplőit, akadályozhatják a tanu láshoz való egyenlő hozzáférés lehetőségeit, mivel a pedagógusok „más nyelvet” beszélnek, olyan nyelvi kódo kat használnak, amelyet sok gyermek nem képes megfejteni. Aronson mozaik módszerének újragondolásával egy innovatív, körkörös osztálytermi tanulási modellt dolgoztunk ki, amely lehetőséget teremt a kutatásban az osztálytermi tanítás különböző aspektusainak tudományos igényű tanulmányozására. Tanulók egymástól történő kölcsönös tanulását vizsgáltuk 2018 tavaszán, amikor 284 gyermek és 74 képzett felnőtt megfigyelő vett részt a tanulási folyamatban. 3 iskolában 30 osztályban tanulmányoztuk a komplex pedagógiai és nevelési folyamatot, minden osztályban 4 alkalommal 45 perces tevékenységek során, ezzel megteremtve a kutatási helyzet validitását. A tanulmány a következő kérdésekre keresi a választ: A körkörös tanulás módszerének mely aspektusai teszik lehetővé a kulturális és nyelvi különbségek kompenzálását? Milyen tényezők tehetik eredményessé a gyerekek egymástól való tanulását, a gyermekek szemszögéből? A gyermek és felnőtt értékelő ürlapok adatait kétféleképpen dolgoztuk fel. 1) R statisztikai program, valamint SPSS statisztikai program alkal mazásával a csoportokat kétmintás t-próbával hasonlították össze. A korreláció számításokat a Spearman-féle korrelációs együttható segítségével végeztük alfa $=0,05$ szignifikancia szinten, amelyet Holm módszerével korrigáltunk több hipotézis tesztelésére. 2) A gyermekek és felnőttek narratív, szöveges válaszait kvalitatív tartalomelemzéssel dolgoztuk fel. A kutatási modellünkben alkalmazott tanulásszervezési eljárások lehetőséget teremtenek a különböző kultúrájú, különböző anyanyelvű és nagyon eltérő társadalmi-gazdasági helyzetű ((diversity) gyermekek számára a tanuláshoz, a tudáshoz való egyenlő hozzáféréshez (equity), az együttműködéshez, a tudáshoz való egyenlő hozzáféréshez (equality), valamint egymás kölcsönös megértéséhez (sustainability). Nemzetközi és magyar modellekkel összhangban módszeregyüttesünk egyszerre tudás- és esélyteremtő modell. Jelenleg Magyarországon és világszerte nagy jelentőségű a gyermekek azon képességének fejlesztése, hogy beilleszkedjenek egy másik ember gondolkodásmódjába. Mások perspektívájának felvétele, eredményeink szerint növeli a tanulás hatékonyságát, egyben jelentős tényező az empátia kialakulásában.

Kulcsszavak: körkörös tanulási módszer, kortársoktatás, perspektivavétel, gyermekek hangja 